\title{
Perinephric Abscess
}

National Cancer Institute

\section{Source}

National Cancer Institute. Perinephric Abscess. NCI Thesaurus. Code C123016.

An abscess that is located outside the renal capsule, but which is within Gerota's space. 